\title{
Molecular characterization of Prunus necrotic ringspot virus isolated from rose in Brazil
}

\author{
Caracterização molecular de Prunus necrotic ringspot virus \\ isolado de roseira no Brasil
}

\author{
Thor Vinícius Martins Fajardo ${ }^{I^{*}}$ Monique Bezerra Nascimento ${ }^{\text {II }}$ \\ Marcelo Eiras ${ }^{\text {III }}$ Osmar Nickel ${ }^{I}$ Gilvan Pio-Ribeiro ${ }^{I I}$
}

- NOTE -

ABSTRACT

There is no molecular characterization of Brazilian isolates of Prunus necrotic ringspot virus (PNRSV), except for those infecting peach. In this research, the causal agent of rose mosaic was determined and the movement (MP) and coat (CP) protein genes of a PNRSV isolate from rose were molecularly characterized for the first time in Brazil. The nucleotide and deduced amino acid sequences of MP and CP complete genes were aligned and compared with other isolates. Molecular analysis of the MP and CP nucleotide sequences of a Brazilian PNRSV isolate from rose and others from this same host showed highest identities of $96.7 \%$ and $98.6 \%$, respectively, and Rose- $\mathrm{Br}$ isolate was classified in PV32 group.

Key words: diagnosis, sequencing, Ilarvirus, PNRSV, ApMV, ArMV.

RESUMO

Inexiste caracterização molecular de isolados brasileiros de Prunus necrotic ringspot virus (PNRSV), exceto aqueles de pessegueiros. Neste trabalho, o agente causal do mosaico da roseira foi determinado e os genes das proteinas de movimento (MP) e capsidial (CP) de um isolado de PNRSV de roseira foram molecularmente caracterizados pela primeira vez no Brasil. As sequências completas de nucleotídeos e de aminoácidos deduzidos da MP e da CP foram alinhadas e comparadas com outros isolados. Análises das sequências de nucleotídeos da MP e da CP do isolado brasileiro de PNRSV de roseira e outros isolados da mesma hospedeira revelaram altas identidades de 96,7\% e $98,6 \%$, respectivamente, sendo o isolado Rose-Br classificado no grupo PV32.

Palavras-chave: diagnose, sequenciamento, Ilarvirus, PNRSV, ApMV, ArMV.
Prunus necrotic ringspot virus (PNRSV) is among a large number of viruses that infect stone fruit trees causing important losses. PNRSV has a worldwide distribution and affects Prunus spp. including peach, nectarine, cherry, apricot, almond and plum trees, besides apple, hop and rose. PNRSV induces necrotic and chlorotic rings, mosaic, deformations in leaves, flowers and fruits, delayed maturation, reduced growth and decreasing productivity in peach; alternatively, the virus may be present latently, not causing symptoms or damage. PNRSV is transmitted by pollen, seed and vegetative propagation methods (FIORE et al., 2008), being a positive-sense RNA virus with a tripartite genome that belongs to the genus Ilarvirus of the Bromoviridae family. RNAs 1 and 2 encode proteins involved in viral replication, whereas RNA3 encodes a 5' movement protein (MP) and a 3' coat protein (CP) which is expressed via a subgenomic RNA4. Sequence comparisons and phylogenetic analyses of the RNAs 3 and 4 and coat proteins revealed that all of the isolates clustered into three different groups, represented by three previously sequenced PNRSV isolates: PV32, PE5, and PV96. PE5-type group was characterized by a 5 ' untranslated region clearly different from that of the other two groups. PV32-type group was characterized by an extra hexanucleotide consisting of a duplication of the six immediately preceding nucleotides (APARICIO et al., 1999). In Rio Grande do Sul State, Brazil, one of the most common viral infections in peach orchads is caused by PNRSV (FIORE et al., 2008). In spite of the

\footnotetext{
'Embrapa Uva e Vinho, CP 130, 95700-000, Bento Gonçalves, RS, Brasil. E-mail: thor.fajardo@embrapa.br. "Corresponding author.

IDepartamento de Agronomia, Universidade Federal Rural de Pernambuco (UFRPE), Recife, PE, Brasil.

IIIInstituto Biológico, Centro de Pesquisa e Desenvolvimento de Sanidade Vegetal (CPDSV), São Paulo, SP, Brasil. 
economical importance of PNRSV to stone fruit crops in Brazil, the molecular characterization of PNRSV isolates, other than those infecting peach, is null.

Three viruses are associated with the range of symptoms of rose mosaic, including PNRSV, Apple mosaic virus (ApMV) and Arabis mosaic virus (ArMV). First report of PNRSV infecting rose in Brazil was detected by serological tests (ALEXANDRE \& DUARTE, 2009). ApMV was already reported in apple orchads in Brazil (FAJARDO et al., 2011). In contrast to PNRSV, it is considered to be non transmissible by pollen or vectors. ArMV that is vectored by nematodes has not yet been reported in Brazil, especially in grapevines. These viruses are classified in the Bromoviridae family, genus Ilarvirus (ApMV) or Secoviridae family, genus Nepovirus (ArMV). Rose mosaic symptoms may vary widely depending on time of the year, temperature, and virus species infecting the plant. Typical symptoms include chlorotic line patterns, ringspots, and mottles in leaves. There may also be yellow net and yellow mosaic symptoms. Symptoms often are evident in spring and early summer but may not be on leaves produced in the summer. Flower distortion, reduction in flower production, flower size, stem caliper at the graft union, and early leaf drop have all been reported. Some infected cultivars may not show any symptoms (PADUCH-CICHAL \& SALA-REJCZAK, 2011). The aim of this research was to determine the causal agent of rose mosaic and molecularly characterize the MP and CP genes of a Brazilian PNRSV isolate from rose.

Some rose (Rosa spp.) plants cultivated in a vineyard marginal area and exhibiting yellow mosaic leaves were observed in the municipality of Lagoa Vermelha, Rio Grande do Sul State, Brazil. Due to symptom uniformity only one of these plants were sampled. Total RNA extractions were performed using RNeasy Plant Mini kit (Qiagen) from 100mg of symptomatic and asymptomatic rose leaves. The primer pairs used for one-step RT-PCR were PNRSV CP: v1 (5'ATGGTTTGCCGAATTTGCAAT3'), c1 (5'CTATATCTCAAGCAGGTCTTCATC3'), MP: v1 (5'ATGGCCGGTGTCAGTAAAAAC3'), c1 (5'TCAAGCACTTCCAGAACTACC3'), ArMV: H428 (5'GCGGCGGATTGGGAGTT3'), C867 (5'CGATGGTAGGGGGAGCGTATT3'), ApMV: v1 (5'ATGGTCTGCAAGTACTGTAA3'), c1 (5'TCATAATTCTAACAAATCTT3'). The RT-PCR in a single step was carried out using One Step RTPCR kit (Qiagen) and reactions were performed according to the manufacturer with $4 \mu \mathrm{l}$ of total RNA. The amplification cycle was: $50^{\circ} \mathrm{C} / 30 \mathrm{~min}$, $95^{\circ} \mathrm{C} / 15 \mathrm{~min}, 35 \mathrm{x}$ : $94^{\circ} \mathrm{C} / 50 \mathrm{~s}, 50^{\circ} \mathrm{C} / 50 \mathrm{~s}, 72^{\circ} \mathrm{C} / 1 \mathrm{~min}$ and $72^{\circ} \mathrm{C} / 10 \mathrm{~min}$. The expected DNA bands were cut and eluted from the gels using the Wizard SV Gel and PCR Clean-Up System kit (Promega).

The eluted DNA fragments were ligated into pGEM-T Easy vector (Promega) and were used to transform Escherichia coli DH5 $\alpha$ competent cells by heat shock. The recombinant plasmids of transformed bacterial colonies were extracted using the Wizard Plus SV Minipreps DNA Purification System kit (Promega) and checked with EcoRI restriction enzyme digestion. The automatic nucleotide sequencing was performed for two clones per ORF (open reading frame). Multiple sequence alignments of nucleotides (nt) and deduced amino acids (daa) and the matrix generation of identities (nt and daa) were performed using Clustal X 1.8 and BioEdit 7.2.5 (HALL et al., 1999) softwares. In the analyses, the complete sequences of the coat (CP) and movement (MP) proteins of PNRSV isolates from rose and some Prunus hosts characterized in Brazil or elsewhere, besides CP and MP sequences of PNRSV type group isolates (PV32, PV96 and PE5) and ApMV as outgroup species available in the GenBank were included. The molecular weight (MW) of the CP and MP viral proteins was calculated using resource at ExPASy. Sixty-five samples of peach canopies and rootstocks and Prunus species from the cultivar collection of Embrapa Clima Temperado (courtesy of B. Ueno) were indexed by RT-PCR for PNRSV using the CP oligonucleotides in the aforementioned conditions.

No amplifications by RT-PCR using ApMV and ArMV primers from total RNA extractions of symptomatic rose leaves were observed. Two DNA fragments of 681 and $852 \mathrm{bp}$ were amplified by RTPCR from the analysed rose sample containing the complete CP and MP nt sequences, the two ORFs in the RNA3 of PNRSV, with 226 and 283 daa, respectively. The predicted molecular mass of the $\mathrm{CP}$ and MP of PNRSV, Rose-Br isolate, was $25.3 \mathrm{kDa}$ and $30.98 \mathrm{kDa}$, respectively, and were very similar to those reported by GUO et al. (1995) for PNRSV from Prunus mahaleb. The two obtained sequences were deposited in the GenBank with accession codes KJ958527 and KM212170, corresponding to CP and MP PNRSV ORFs, respectively. Rose isolates of PNRSV were already detected and molecularly characterized in India (KULSHRESTHA et al., 2013), Poland (PADUCH-CICHAL \& SALA-REJCZAK, 2011) and France (MOURY et al., 2001).

The alignment between the CP nucleotide sequence of PNRSV, Rose-Br isolate, and seven sequences of rose isolates of PNRSV from India, Poland and China available in GenBank showed high identity ranging from $97.3 \%$ to $98.6 \%$, suggesting 
limited variability among CPs of analyzed isolates. When the comparison was between the PNRSV $\mathrm{CP}$, Rose- $\mathrm{Br}$ isolate, and the PNRSV CP nucleotide sequences of three Brazilian peach isolates (EF565264EF565266), lower identity values were verified (94.1\% to $97.5 \%$ ). Phylogenetic analysis of PNRSV coat protein sequences from rose and Prunus hosts exhibited the formation of three monophyletic clusters defined for PNRSV groups (PV32, PV96 and PE5) (Figure 1A). All studied rose isolates of PNRSV were grouped as PV32, thus the CP gene of Rose- $\mathrm{Br}$ isolate was six nucleotides longer at positions 119-124 than CP genes of the other PV96 and PE5 isolates. Addition of six nucleotides resulted in two corresponding extra amino acids asparagine and arginine in the putative $\mathrm{CP}$ of the virus. The extra residues of the PV32 group are inside the RNA-binding domain described for PNRSV. Amino acids from 25 to 50 are essential for the protein to bind PNRSV RNA in vitro (SALA-REJCZAK \& PADUCH-CICHAL (2013). KULSHRESTHA et al. (2013) and SALA-REJCZAK \& PADUCH-CICHAL (2013) performed sequence analysis of $\mathrm{CP}$ and also revealed that the rose isolates of PNRSV from India and Poland, respectively, belong to PV32 group of PNRSV isolates. In addition to the mentioned features of PV32 group members (APARICIO et al., 1999), additional group and host specific features were also identified. Presence of methionine at position 90 in the amino acid sequence alignment of PNRSV CP gene (belonging to PV32 group) was identified as the specific conserved feature for the rose isolates of PNRSV (KULSHRESTHA et al., 2013), including the Brazilian rose isolate (KJ958527).

APARICIO et al. (1999) mentioned that although most of the variability was observed in the first third of the CP, the amino acid residues in this region, previously thought to be functionally important in the replication cycle of the virus, were strictly conserved. No clear correlation between molecular variability, primary sequence of the gene for MP or CP, biological properties, geographical origin, host specificity or symptomatology could be observed (APARICIO et al., 1999; SCOTT et al., 1998). Thus it is worth mentioning the closest clustering of PNRSV isolate from roses as demonstrated in figure 1A. Analysis of the different isolates revealed a lack of association between specific nucleotide or amino acids patterns and host origin, symptomatology or geographic area, although the majority of isolates from phylogroups PV96 and PV32 tend to exhibit latent/mild or chlorotic/necrotic symptoms, respectively. Molecular analyses of the coding sequences of the $\mathrm{CP}$ and the MP revealed that both proteins are highly conserved, independently of the host and geographical origin of the isolates (FIORE et al., 2008).

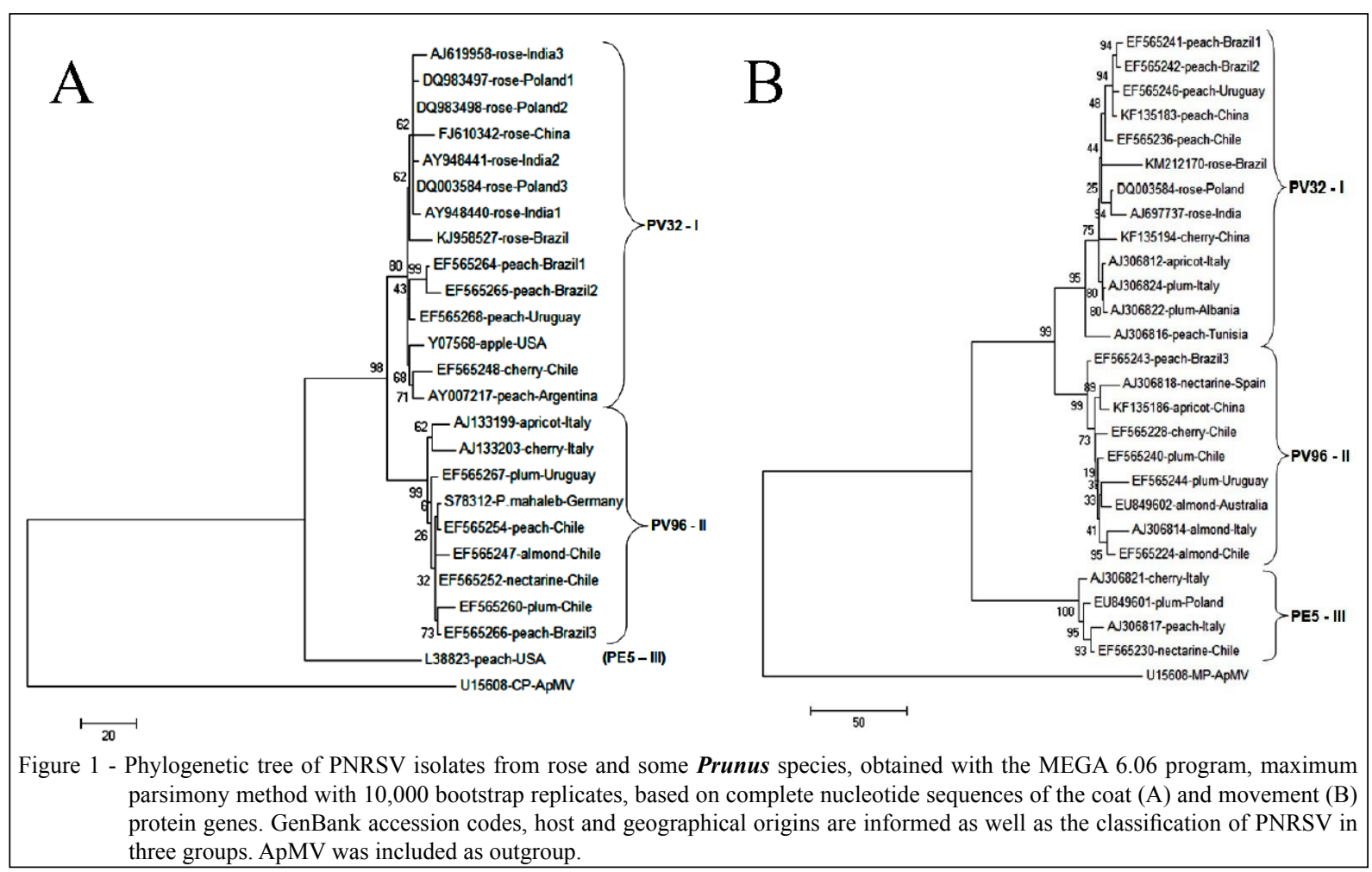

Ciência Rural, v.45, n.12, dez, 2015. 
SALA-REJCZAK \& PADUCH-CICHAL (2013) have studied the nucleotide sequences of PNRSV CP in eleven Polish isolates, from different Prunus and Rosa species and four isolates from Australia, Hungary and Italy. Results also indicated no association between the host species or the geographic origin and the PNRSV CP sequence specificity. Our results regarding rose isolate of PNRSV and phylogenetic analysis (Figure 1A) are very similar to those obtained by FIORE et al. (2008) and SALA-REJCZAK \& PADUCH-CICHAL (2013) to PNRSV from some Prunus and Rosa species.

The alignment between the MP nucleotide sequence of PNRSV, Rose-Br isolate, and only two sequences of rose isolates of PNRSV from India and Poland available in GenBank showed high identity ranging from $96 \%$ to $96.7 \%$. Comparison between MPs of Indian (AJ697737) and Polish (DQ003584) isolates showed $98.9 \%$ nt identity. When the comparison was between the PNRSV MP, Rose-Br isolate, and the PNRSVMPnucleotide sequences of three Brazilian peach isolates (EF565241-EF565243), lower identity values were verified $(93.5 \%$ to $96.5 \%)$. Phylogenetic analysis of PNRSV movement protein sequences from rose and Prunus hosts also exhibited the formation of three monophyletic clusters previously defined for PNRSV groups (PV32, PV96 and PE5). All three rose isolates of PNRSV were grouped as PV32, together with other isolates of PNRSV from Prunus (cherry, apricot, peach, plum) species (Figure 1B). PNRSV isolates classified as PE5 group had 855 nucleotide length in MP sequence instead of $852 \mathrm{bp}$ of PV32 and PV96 groups. MOURY et al. (2001) found that all 27 rose isolates tested infecting P. persica seedlings, and three out four Prunus PNRSV isolates tested were weakly infectious in Rosa indica plants. These data suggestted adaptation of PNRSV isolates from Prunus spp., but not from rose, to their host plants. However, comparisons of the coat protein gene sequences for rose isolates indicated that they do not form a distinct phylogenetic group and show close relations to Prunus spp. isolates. According to MOURY et al. (2001), progression of the rose mosaic disease under greenhouse conditions was very slow, which should make PNRSV easy to eradicate through sanitary selection.

Another result obtained in this research was the incidence of PNRSV infecting one of the most important hosts of this virus. Four out the 65 evaluated peach and Prunus samples (6.2\%) were infected with PNRSV, revealing a low incidence of this virus in the evaluated germoplasm collection. This incidence could be explained by appropriate phytosanitary conditions under which this Prunus collection has been maintained. The present research constitutes the first molecular characterization of the complete CP and MP genes of a Brazilian PNRSV isolate from rose and expands the knowledge on the genetic variability and incidence of this pathogen.

\section{REFERENCES}

ALEXANDRE, M.A.V.; DUARTE, L.M.L. Identificação do Prunus necrotic ringspot virus em roseira. Tropical Plant Pathology, v.34, p.S274, 2009.

APARICIO, F. et al. Molecular variability among isolates of Prunus necrotic ringspot virus from different Prunus spp. Phytopathology, v.89, p.991-999, 1999. Available from: <http:// apsjournals.apsnet.org/doi/pdf/10.1094/PHYTO.1999.89.11.991>. Accessed: Apr. 24, 2015.

FAJARDO, T.V.M. et al. Detecção e caracterização molecular dos genes da proteína capsidial de ilarvírus e ampelovírus que infectam fruteiras temperadas. Ciência Rural, v.41, p.5-9, 2011. Available from: <http://dx.doi.org/10.1590/S0103-84782011000100002>. Accessed: Apr. 24, 2015.

FIORE, N. et al. Genetic diversity of the movement and coat protein genes of South American isolates of Prunus necrotic ringspot virus. Archives of Virology, v.153, p.909-919, 2008. Available from: < http://link.springer.com/article/10.1007/s00705008-0066-1>. Accessed: Apr. 24, 2015.

GUO, D. et al. Prunus necrotic ringspot ilarvirus: nucleotide sequence of RNA3 and the relationship to other ilarvirus based on coat protein comparison. Journal of General Virology, v.76, p.1073-1079, 1995. Available from: <http://vir.sgmjournals.org/ content/76/5/1073.short $>$. Accessed: Apr. 24, 2015.

HALL, T.A. BioEdit: a user-friendly biological sequence alignment editor and analysis program for Windows 95/98/NT. Nucleic Acids Symposium Series, v.41, p.95-98, 1999.

KULSHRESTHA, S. et al. Molecular characterization and intermolecular interaction of coat protein of Prunus necrotic ringspot virus: implications for virus assembly. Indian Journal of Virology, v.24, p.235-241, 2013. Available from: <http:// link.springer.com/article/10.1007\%2Fs 13337-013-0140-5>. Accessed: Apr. 24, 2015.

MOURY, B. et al. Survey of Prunus necrotic ringspot virus in rose and its variability in rose and Prunus spp. Phytopathology, v.91, p.84-91, 2001. Available from: <http://apsjournals.apsnet.org/doi/ pdf/10.1094/PHYTO.2001.91.1.84>. Accessed: Apr. 24, 2015.

PADUCH-CICHAL, E.; SALA-REJCZAK, K. Biological and molecular characterization of Prunus necrotic ringspot virus isolates from three rose cultivars. Acta Physiologiae Plantarum, v.33, p.2349-2354, 2011. Available from: <http://link.springer. com/article/10.1007/s11738-011-0775-z>.

SALA-REJCZAK, K.; PADUCH-CICHAL, E. Molecular variability of the coat protein gene of Prunus necrotic ringspot virus isolates. Acta Scientiarum Polonorum, Hortorum Cultus, v.12, p.35-42, 2013. Available from: <http://www.acta. media.pl/pl/full/7/2013/000070201300012000020003500042. pdf $>$. Accessed: Apr. 24, 2015.

SCOTT, S.W. et al. The coat proteins and putative movement proteins of isolates of Prunus necrotic ringspot virus from different host species and geographic origins are extensively conserved. European Journal of Plant Pathology, v.104, p.155-161, 1998. Available from: <http://link.springer.com/ article/10.1023/A\%3A1008668129926>. Accessed: Apr. 24, 2015. 